University of Nebraska - Lincoln

DigitalCommons@University of Nebraska - Lincoln

Agronomy \& Horticulture -- Faculty Publications

Agronomy and Horticulture Department

1969

Development, Differentiation, and Yield

John Heslop-Harrison

University of Wisconsin, Madison, Wisconsin

Follow this and additional works at: https://digitalcommons.unl.edu/agronomyfacpub

Part of the Plant Sciences Commons

Heslop-Harrison, John, "Development, Differentiation, and Yield" (1969). Agronomy \& Horticulture -Faculty Publications. 195.

https://digitalcommons.unl.edu/agronomyfacpub/195

This Article is brought to you for free and open access by the Agronomy and Horticulture Department at DigitalCommons@University of Nebraska - Lincoln. It has been accepted for inclusion in Agronomy \& Horticulture -Faculty Publications by an authorized administrator of DigitalCommons@University of Nebraska - Lincoln. 
Published in Physiological Aspects of Crop Yield: Proceedings of a symposium sponsored by the University of Nebraska, the American Society of Agronomy, and the Crop Science Society of America, and held at the University of Nebraska, Lincoln, Nebr., January 20-24, 1969. Edited by Jerry D. Eastin, F. A. Haskins, C. Y. Sullivan, C. H. M. Van Bavel, and Richard C. Dinauer (Madison, Wisconsin: American Society of Agronomy \& Crop Science Society of America, 1969). Copyright (C) 1969 American Society of Agronomy \& Crop Science Society of America. Used by permission. 


\title{
13
}

\section{Development, Differentiation, and Yield}

\author{
JOHN HESLOP-HARRISON \\ University of Wisconsin \\ Madison, Wisconsin
}

\section{INTRODUCTION: FEATURES OF THE DEVELOPMENTAL PROCESS IN PLANTS}

The task of reviewing some of the ways development and differentiation may act as determinants of economic yield would be much simpler had knowledge advanced to a point where the basic principles concerned in the control of these processes in eukaryotic organisms were clear. Unfortunately, this stage has not yet been reached. There is no shortage of schemes and hypotheses to set beside a mountain of observational and experimental data, but the unifying thread which might allow us to pick out the significant and reject the irrelevant in any particular context is still lacking. What is incontestable is that development and differentiation are manifestations of gene function, so the fundamental problem can at least be defined: it is to understand how gene action is governed in ontogeny so as to give orderly expression to the potentialities attained during the evolutionary history of a species, producing an organism that is harmoniously coordinated both within itself and with the environment. I will begin by considering some general aspects of this problem as it applies to higher plants.

It is sometimes didactically convenient to separate the concepts of growth, differentiation, organogenesis and development; yet the processes to which we apply these terms are in no sense independent in the life of the plant. Development is the progression through time of organogenetic events, and the ontogeny of each organ is based upon particular patterns of cell and tissue differentiation. Growth, in the sense both of increase of cell number and of cell size, is an inevitable accompaniment throughout.

What we witness is, of course, the working out of the potential present in the genome of the zygote. According to present understanding, the two functions of the gene as a stretch of DNA are to replicate and to direct the synthesis of proteins of specific amino acid sequence through the intermediacy of mRNA. All manifestations of gene action, 
morphological and functional, have therefore to be traced back to the activities of specific proteins; and differentiation in cells and tissues is to be interpreted as the outcome of qualitative and quantitative changes in protein complements, and of the modulation of the functional activities of proteins in enzymatic and other roles by various endogenous and exogenous agencies.

Given that differentiation is of this nature, regulation could obviously be applied at different points in the causational chain. We have just passed through a period when the most popular view has been that control is mostly imposed at the level of the gene itself, determining whether it should be transcribed or not in individual nuclei in accordance with the circumstances of the cell. In so far as protokaryotic microorganisms may be said to show differentiation, it may well be that it is at this level that its regulation is largely effected; but with eukaryotes it is looking more and more likely that much of the control of gene expression is exerted at later links in the chain (Cline and Bock, 1966). It is unnecessary to review this aspect here, but in the context of higher plants it is noteworthy that the presence of molecules with cytokinin activity in tRNA (review, Helgeson, 1968) at least suggests the possibility that they may be concerned in regulating translation, while schemes have been offered imputing to auxins a role at this same level (Armstrong, 1966).

There are certainly very good circumstantial reasons for supposing that control is imposed at several levels in the growth and differentiation of higher plants. Competence phenomena in general point to this: whenever a tissue or an organ shows temporal variation in its capacity to react to a stimulus, the conclusion is unavoidable that it is passing through states of "cryptic" differentiation. The attainment of competence in some tissues may represent the completion of a transcriptional step; the later, overt, differentiation could then be the consequence of activation at translational or later points. This is evidently so in seeds, where the mRNA concerned with the early protein synthesis associated with germination is present in masked form during dormancy (Waters and Dure, 1966; Chen et al., 1968).

On the other hand, it can hardly be assumed that differences in the competence of specific tissues to respond to hormonal and other stimuli always depends upon variation in pre-existing mRNA populations. In many cases the response to the inducing stimulus itself involves the synthesis of RNA. An example pertinent is the grass Lolium temulentum. The genotype of this grass used by Evans (1964) initiates an inflorescence in response to a single inductive long day; actinomycin D applied the morning following this experience suppresses the response, suggesting that this is a critical period for the synthesis of an RNA fraction specifically associated with flowering. In Lolium, as in spicate grasses generally, the formation of spikelets begins in specific sites on the flanks of the shoot apex, axillary to the leaf primordia. These sites represent islets of "competent" tissue, which have attained their potential for reacting to the inductive stimulus by some prior process of differentiation, probably each at the time of initiation during successive plastochron cycles (Knox and Evans, 1966).

Some other features of flowering merit attention. Flower initiation 
always follows a period of vegetative growth, and the event may be viewed as a transition by apical meristems from leaf production to the sequential formation of floral parts. Where the terminal meristem is converted in this manner, the product is a single flower, and when the first or later order axillary buds are so transformed, the result is an inflorescence. The balance between vegetative growth and flowering is thus between the factors tending to direct appendicular structures into pathways of differentiation characteristic of leaves, and those selecting instead the pathways leading to perianth, stamens and carpels. Lang (1965a) has provided a very thorough review of the role of environmental factors in controlling this balance. Some of the responses observed in experiment appear to point to the existence of a positive, switch-like mechanism, but in most species the environmental control is no more than modulating, affecting the rate of progression from vegetative to reproductive growth, but not determining in any absolute sense whether it occurs or not. The implication of this is that the transition to flowering is part of a rather inflexible developmental program, governed in its essentials by autonomous controls (Nougarède, 1965; Heslop-Harrison, 1969). It is unfortunate that the concentration of photoperiodic research on a few rather exceptional plants has helped to conceal this point by over-emphasizing the more superficial, rate-modulating aspect of the control mechanism.

What, then, can be said about the nature of endogenous controls of gene expression in development? Some examples seem to indicate that an intrachromosomal regulatory mechanism is at work, exposing genes for transcription according to predetermined programs. An example from the work of Hotta and Stern (1965) on the pollen mother cells of lily (Lilium sp.) illustrates this, and shows that programed gene action in development is not a matter of substrate-induction. During one specific period in the life of the anther, the enzyme thymidine kinase is produced, and its activity subsequently decays. The enzyme can be induced by exogenously-supplied thymidine during only a short interval of time, and this interval begins just before thymidine kinase appears naturally. This result suggests that the locus concerned is made accessible just as its transcription is required in the general developmental program.

Sequential gene "exposure" can be referred to the operation of unknown, time-related controls at the chromosomal level, but it is more plausibly interpreted as resulting from the working of a kind of relay system, where the functioning of each gene group is contingent upon the work of the preceding, and leads in turn to the activation of the next (Stern, 1964). A model of this kind has some attraction in seeking to explain the behavior of the plant apex (Heslop-Harrison, 1963), but there is as yet little to substantiate it. What evidence there is relates to the "determination" of lateral appendages during vegetative growth (Cutter, 1965). Operative experiments (Wardlaw, 1949; Sussex, 1954, 1955) and organ culture (Steeves, 1962) suggest that the fate of a primordium initiated on a flank of the apical meristem is affected by influencespresumably chemical in nature-reaching it from the apical dome itself, and by interaction with other, neighboring primordia. Thus the youngest prospective leaf primordia produce centric structures when isolated 
from the growth cone; but later, after some decisive event or events occurring over a definable period of time, changes occur in the primordia which constrain them to develop in a leaf-like manner, expressing dorsiventral symmetry. This kind of evidence suggests that there are short-range humoral agencies in the apex concerned with the selection of prospective developmental pathways for the primordia as they originate. These, then, would be the agencies responsible for imposing the condition of competence referred to in previous paragraphs.

These considerations show that there is an urgent need for plant physiologists to come to grips with the neglected problem of the metamerism of the shoot system so characteristic of higher plants. The growth of the plant is open-ended, in the sense that apices are persistently meristematic and continuously concerned with organogenesis. They are engaged in an endless succession of cycles, but in each they are laying out a sequence of comparatively few structures. Each cycle represents the definition of a "phytomer" in the terminology of classical structural botany, and the phytomer is never seen to better advantage than in the corn plant (Zea mays L.) (Arber, 1934; Galinat, 1959). Now the circumstance that has its morphological expression in the sequence: node, root site, leaf, axillary bud, internode, must be physiological at base. In the terms of the preceding discussion, there must be some cyclical regulatory mechanism operating through each plastochron to determine the potential of different cell lineages according to the times they are initiated. With the move towards reproduction, more potentialities are laid out, to be realized or not according to the general hormonal situation in the plant as a whole (Fig. 13-1).

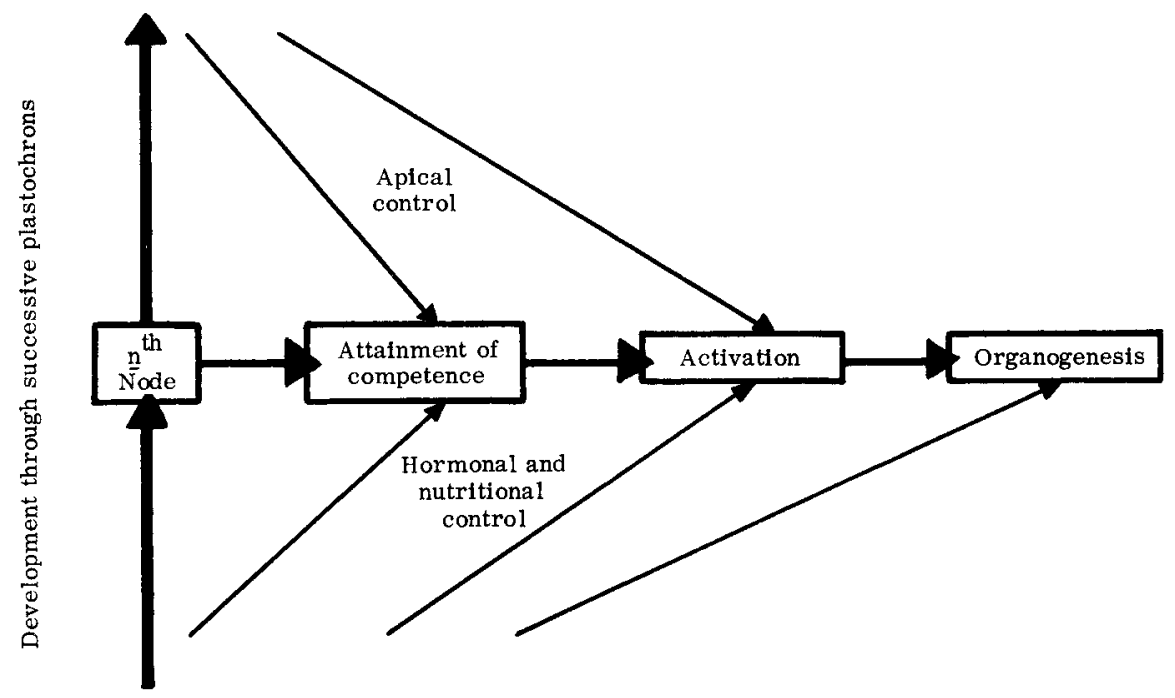

Fig. 13-1-Events leading to organogenesis in the shoot system. At each node, cell lineages are defined which attain competence for certain types of differentiation. Whether the selected pathway is entered depends upon whether or not activating stimuli are received; if they are, organogenesis proceeds. The potential pathways available at each node change as development progresses. 
As we have seen, the experiments of Evans (1964) and others do strongly suggest that the potentiation of particular tissues in the neighborhood of the apex is not itself the completion of transcription. The alternative is that the determining act is the exposure of part of the genome for transcription; or, stated negatively, the blanking off of those parts not to be read in the cell, tissue or organ concerned. This would seem to be the deduction from the experiments of Huang and Bonner on the synthesis of the storage protein of the pea cotyledon (Pisum sp.) (Bonner, 1965). RNA was synthesized when isolated chromatin from the young cotyledons was provided with polymerase and substrates, and this RNA, supplied in turn with messenger-free ribosomes, appropriate co-factors and substrates, supported the synthesis of the storage globulin, recognized in the experiment by its immunological properties. When chromatin from vegetative buds was tested, it was found to be less effective in directing these same syntheses by a factor of up to eight. The interpretation given to these results by Huang and Bonner was that different constellations of genes are open for transcription in the chromatin from the two types of tissue, and they supported the view that the "blocking" agent is the chromosomal histone.

A difficulty lies in understanding how predifferentiations, if they do depend upon differing states of gene accessibility, can be transmitted through cell lineages (Heslop-Harrison, 1967). Clearly, if the transmitted changes depend upon permanent gene inactivation, they are mutations, not differentiations in the normal sense. Regenerative experiments, now performed for almost all plant organs, show that organ determination is not of this character. Knowledge of mitotically transmissible, specific, reversible "gene-blocking" agents is very hazy for higher organisms, if it can be said to exist at all. The histone hypothesis has not yet been developed to a point where it offers a satisfactory explanation of the specificity observed in differentiation, nor of the transmissibility apparent in so many examples of development and differentiation. There remains the possibility that controls of gene expression of the operon type are responsible (Jacob and Monod, 1963). These could be envisaged as carrying repressed states through mitotic cycles because of the persistence of extranuclear elements of the circuit through mitotic contraction, or as cooperating in maintaining common conditions of partial differentiation in tissues by the transfer of repressors between cells. The operon scheme therefore can offer some useful models, but there is no unequivocal evidence yet of the existence of such control circuits in higher organisms.

Once a primordium or a volume of axial tissue has been committed to a particular developmental pathway by virtue of its time of initiation and position relative to the apex, whether its potential is realized or not depends on the working of a further superstructure of control, that embodied in the general hormonal and nutritional milieu of the whole plant. At this level, also, control may be imposed so positively as to amount effectively to a "determination," as in the suppression of axillary bud development by a strongly dominant apex. Figure 13-2 is a chart of some of the alternative developmental pathways open during the growth of the corn plant. At the "switch" points marked, development can be deflected in the directions shown by photoperiodic, temperature or 

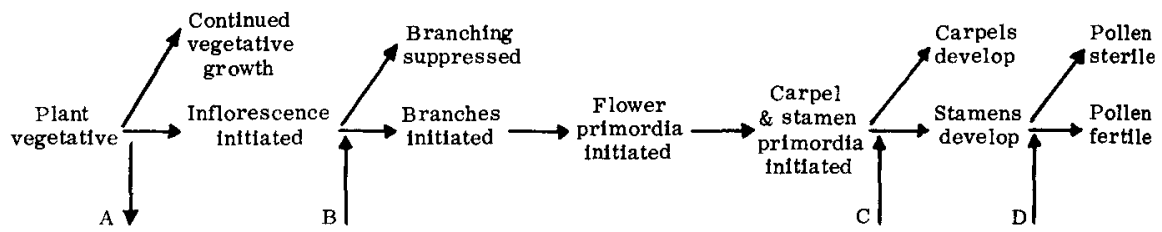

Fig. 13-2-Alternative pathways in the flowering of Zea mays. The axial sequence represents the route leading to a fertile male inflorescence in a normal annual cycle of growth. At A, B, C and D the developmental pathway can be deflected in the direction indicated by short-day experience. From HeslopHarrison (1961).

chemical treatments (Heslop-Harrison, 1961; Moss and Heslop-Harrison, 1968). Once made, the decision at each of these points is in effect irreversible, so that they represent commitments yet more extreme than axillary bud inhibition. The specificity is strikingly illustrated in the growth of the individual flower primordium in corn. All primordia, in tassel and ear, pass through a primitively monoclinous condition. Then, according to the position in the plant and prior temperature and photoperiodic experience, stamen growth is suspended in the ears and gynoecial growth in the florets of the tassel. It can be shown that each floret passes through a phase of sensitivity during which sex determination takes place, and there is circumstantial evidence to show that the decisive events are local ones, not engaging all the tissues of the inflorescence (Heslop-Harrison, 1961). Once complete, this determination is certainly irreversible, since the primordia of the alternate sex atrophy. Similar evidence exists for sex determination in the monoecious cucurbits, where the early lability of the bud primordium and its sensitivity to control by auxins and gibberellins has been demonstrated in culture in vitro (Galun, Jung, and Lang, 1962).

Even though differentiation continues to present so many enigmas, the for egoing paragraphs show that it is possible to distinguish a hierarchy of control levels in higher plants. In the following section, some features of storage organ formation are examined in the light of this fact.

\section{STORAGE TISSUES: CHARACTERISTICS AND DEVELOPMENT}

Recent reviews of the morphology and cytology of storage organs include those of Weber $(1958 a, b)$ and Wanner (1958). The characteristic cytological features of storage tissues are associated with the kinds of reserves accumulated, and not with the nature of the storage structure in organographic terms. This means that the differentiations concerned with the acquisition of the storage function can be superimposed 
upon those undergone in the normal course of organogenesis. These differentiations may involve no more than trivial changes in cell organization, as is often found when soluble compounds are stored, or they may demand far-reaching structural modifications, particularly in organelles. In starch-storing tissues, proplastids may develop directly into amyloplasts andpass through no stage where an extensive lamellar system is formed, or, as in the storage stems of Pellionia, amyloplasts may be formed from previously functional chloroplasts by the regression of the lamellar system. Plastids may also undergo radical structural reorganization for the storage of lipids and proteins. However, lipid reserves more commonly accumulate in spherosomes, which according to one current view are derived from embayments of the endoplasmic reticulum. Some types of protein inclusions, both amorphous and crystalline, appear to have a similar origin, although there is much yet to be found out about the ontogenetic derivation of many classes of reserve proteins.

In some tissues, specialization for a storage function may represent a terminal differentiation; in others it clearly does not. Although the state of endopolyploidy has yet to be established for many types of storage organs, it is probable that the chromosome number does often increase in the cells during differentiation (d'Amato, 1964), and it is likely that the chromosomes of some become polytenic. These are devices serving to increase the number of functional loci, and they are characteristic of glandular and other types of tissue where rapid synthesis of a few products is required over a comparatively short period of time. Highly endopolyploid or polytenic cells probably never revert to division and growth in the natural tissue. Storage may also culminate in irreversible damage to organelles, as seems to be true of amyloplasts in endosperm (Badenhuizen, 1958); again, it would seem improbable that cells modified to this extent could revert to a meristematic state.

On the other hand, some metabolic activity must be resumed in storage structures connected with perennation, even if only for the purpose of mobilizing the reserves, and extensive "re-differentiation" may follow, as when storage cotyledons become photosynthetic during germination. In climacteric fruits, the truly terminal differentiation is that which leads to the climacteric itself, as in the banana (Musa sp.) (Sacher, 1967). Right up to this time, banana fruit tissue can be caused to resume growth, to lose starch content, and to produce a callus of actively proliferating cells (Mohan Ram and Stewa rd, 1964). The many similar demonstrations that the storage tissues of fruits, tubers, rhizomes, corms, and storage roots can be caused to proliferate in culture in vitro and even to regenerate plants proves that at least some cells have retained totipotency, and perhaps more importantly, genomic balance. These experiments also cast light on some of the reasons for the metabolic inactivity of mature storage tissues, since the induction of growth uniformly requires that auxin and cytokinin should be supplied from exogenous sources. Growth induction involves an initial lag phase, during which many syntheses are resumed with concomitant farreaching changes in organelles (Israel and Steward, 1966). 


\section{A. Biological Role of Storage Organs}

In general, storage tissue serves either to provide incentives for animal collaboration in haplophase or diplophase dispersal, or to carry reserves accumulated in one season through a period inimical to growth for use in organogenesis, or for some reproductive purpose, in the next. Fleshy fruits are the prime examples of the first function; endosperm and all types of storage structures derived by the modification of vegetative organs characterize the second. The biological significance of storage organs is thus to be understood first in ecological termsspecifically, in relation to adaptation to climate and particular types of biota. Plant survival in any habit but the most uniform depends upon the acquisition of a developmental cycle fitting growth and reproduction to the annual march of the seasons. For annuals, this will mean an adjustment of the relative durations of seed dormancy, vegetative growth, flowering, seed maturation, and fruit set to optimize the opportunities for dispersal and establishment each year. For perennials the survival of the individual will require the accumulation of reserves in vegetative organs and a strict regulation of growth periodicity and bud dormancy.

For each different climatic complex and each habitat or microhabitat, natural selection will determine what life forms will dominate, and will further ensure the continuous adjustment and readjustment of the developmental cycles of species populations to maintain optimum "fit" to the seasonal cycle. This serves to emphasize the time-keeping aspect of developmental processes, and to bring out the fact that where accurate temporal regulation of periodicities is essential for survival, selection will favor the adoption of reliable environmental "clocks" for the purpose. Here, then, lies the significance of the photoper iodic reaction, and of the temperature responses controlling seed and bud dormancy and vernalization.

The specific effects of light and temperature upon developmental periodicities are all of the inductive type, in the sense that the perception of the stimulus over one period determines behavior at some future time-often, in terms of a growing apex, many cell generations later (Lang, 1965a). This device provides the element of anticipation necessary for survival in climates with seasons inimical to growth. An important point is that the activating signals are not necessarily related directly to the environmental conditions that will prevail when the response is executed. This is obvious enough for the examples of flowering and control of winter dormancy just mentioned; but the principle applies, mutatis mutandis, with all adaptively significant developmental periodicities, including the differentiation of vegetative storage tissues. So it may be concluded that the stimuli potentiating tissues for storage and launching the growth of storage organs will normally act earlier than, and not be identical with, those later to be concerned with the synthesis and translocation of the reserves themselves. This proposition, justified here from theoretical considerations, is of course well enough substantiated from observation. Bulbing, tuberization, corm formation are all typically responses to photoperiod and inductive tem- 
perature experience, sharing many of the characteristics of the flowering response (Gregory, 1965; Nitsch, 1966).

\section{B. Development of Storage Structures}

It is usually possible to distinguish three phases in the development of a vegetative storage structure after its initiation, (i) an early period of increase in cell number leading to, or overlapping with, (ii) a period of cell expansion and reserve accumulation, which gives place in turn to (iii), a period of relative metabolic inactivity, amounting often to dormancy. These phases vary in their duration, and may occur cyclically. Leading from the arguments of preceding paragraphs, the sequence of events is as in Fig. 13-3. This scheme postulates that the potentiation of the tissue for storage depends upon endogenous controls, modulated to some degree through the general hormonal milieu of the plant. The initiation of growth in competent tissue is represented as being primarily dependent upon general hormonal control, whereas size and storage capacity must necessarily be related, as shown, to availability of mineral nutrients, water and photosynthate. A feed-back loop, discussed in more detail below, is shown as influencing translocation,

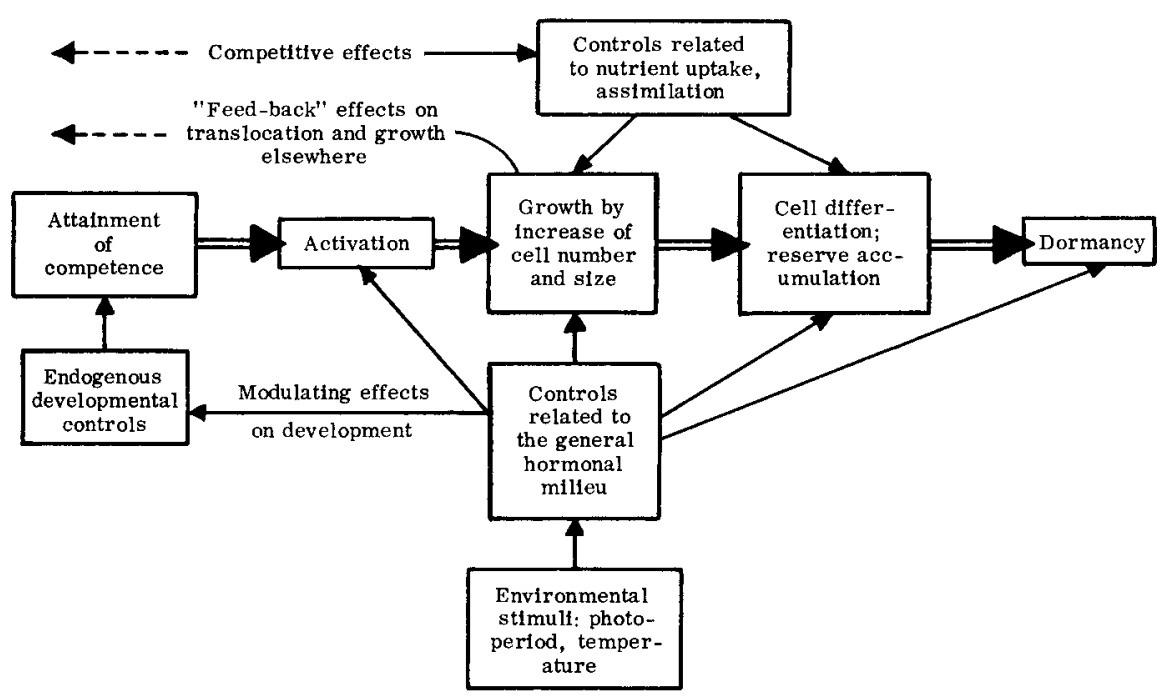

Fig. 13-3-Scheme for the differentiation of a vegetative storage structure. The axial sequence begins at a time when a volume of tissue competent to differentiate for the storage function has been defined. Activation is shown as being primarily under hormonal control, and also the ultimate passage into dormancy. Growth and reserve accumulation are governed both nutritionally and hormonally. 


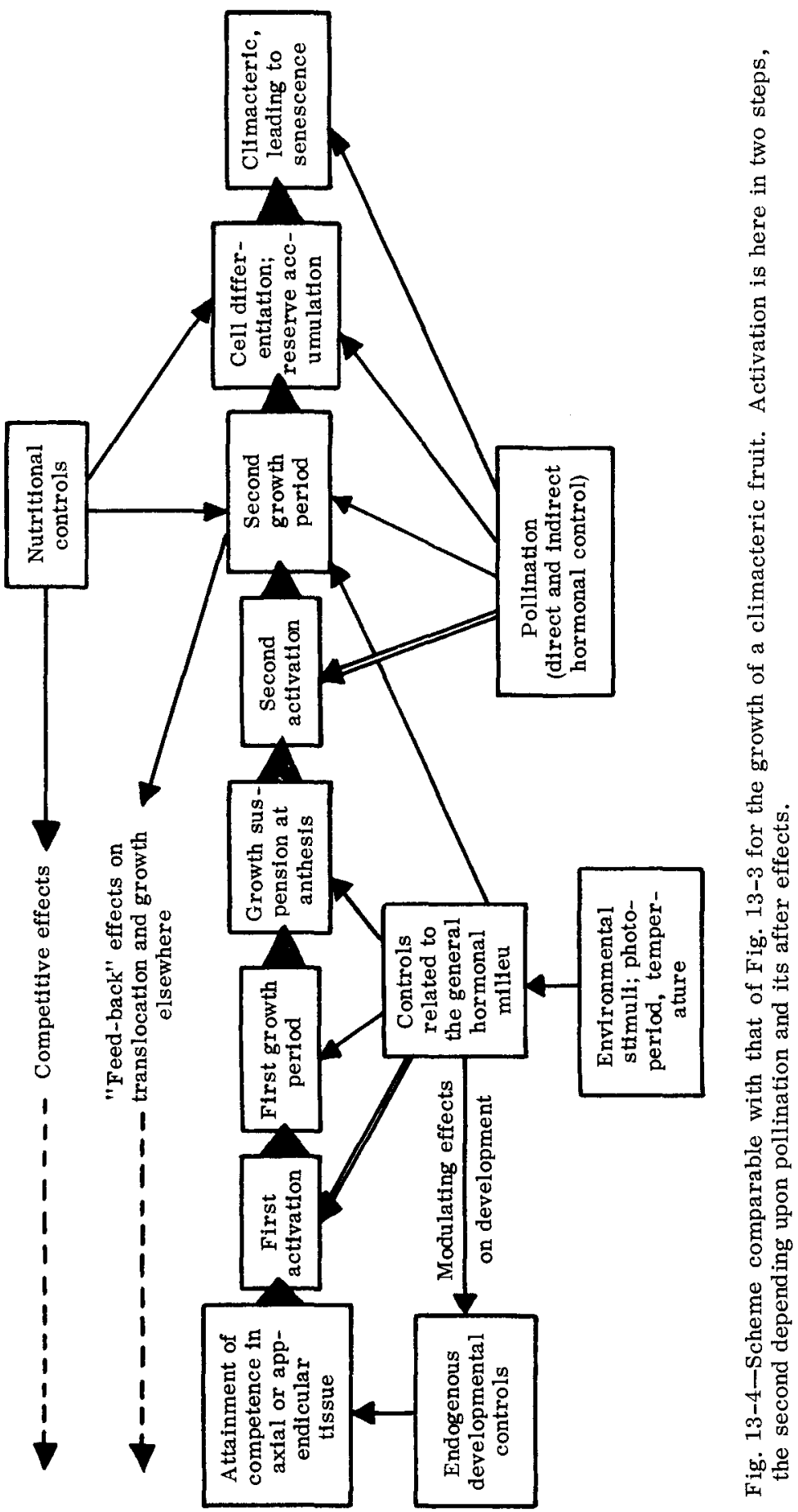


and another as affecting growth elsewhere in the plant. The control of the onset of dormancy is imputed to hormonal control from outside of the developing organ, again allowing for time-regulation through photoperiod.

A similar scheme can be drawn up for fruits, but it must necessarily take into account other strata of control. An outline is given in Fig. 13-4. The first activation phase is initiated with the onset of flower formation; the resulting growth is arrested or drastically reduced around the time of anthesis. The second activation phase depends on the consummation of pollination. The stimulation here may be threefold: through the growth substances borne by the pollen itself; through the activation of growth-substance synthesis in ovary tissues by cofactors brought in by the pollen tube, and, later, through growth substances released from the developing embryos and endosperms after the successful completion of fertilization. Again, nutritional control enters as a determinant of size, and there are feed-back effects on the translocation system. The culmination of the pathway in many fruits is entry into the climacteric, which is probably timed both by local controls and the general hormonal environment of the plant.

A third scheme, Fig. 13-5, relates to the development of seed reserves. Here five organisms are involved: the parental sporophyte, the female gametophyte, the male gametophyte, the diploid embryo and the triploid endosperm (the justification for regarding the endosperm as a separate organism is primarily genetical, but the concept also has its physiological usefulness). To simplify this scheme, the time sequence is started at the point where the female gametophyte is already differentiated: the antecedent circumstances would be those leading to flowering, carpel activation, meiosis, and megaspore germination. There are some plants where meiosis and embryo-sac development are contingent upon pollination, but this seems rare, and in general it is the further development of the egg and the primary endosperm nucleus that demands the stimulus of pollination-or, more specifically, fertilization. As in the examples of vegetative storage organs, the duration of growth before dormancy is governed in part from without, although here it is a question of a teleonomic influence of one generation upon another.

It is worth noting in passing that fruit and seed development offer excellent models for the interplay of competent-tissue and activatingstimulus which elsewhere has to be inferred from experiment with isolated organs and tissues, since one link in the natural control pathway lies outside of the plant. Growth of the ovary is arrested at anthesis; but ovary tissues are competent to respond to the stimuli accompanying, and generated by, pollination. Similarly, egg and primary endosperm nucleus are blocked unless further development is promoted by fertilization. In both of these examples, the requirement for the exogenous stimulus is bypassed in certain genotypes, so that the fruit develops parthenocarpically, or the egg and endosperm parthenogenetically.

\section{The Hormonal Factors}

The schemes discussed above help to direct attention to various persistent lacunae in our knowledge of hormonal function in the control 


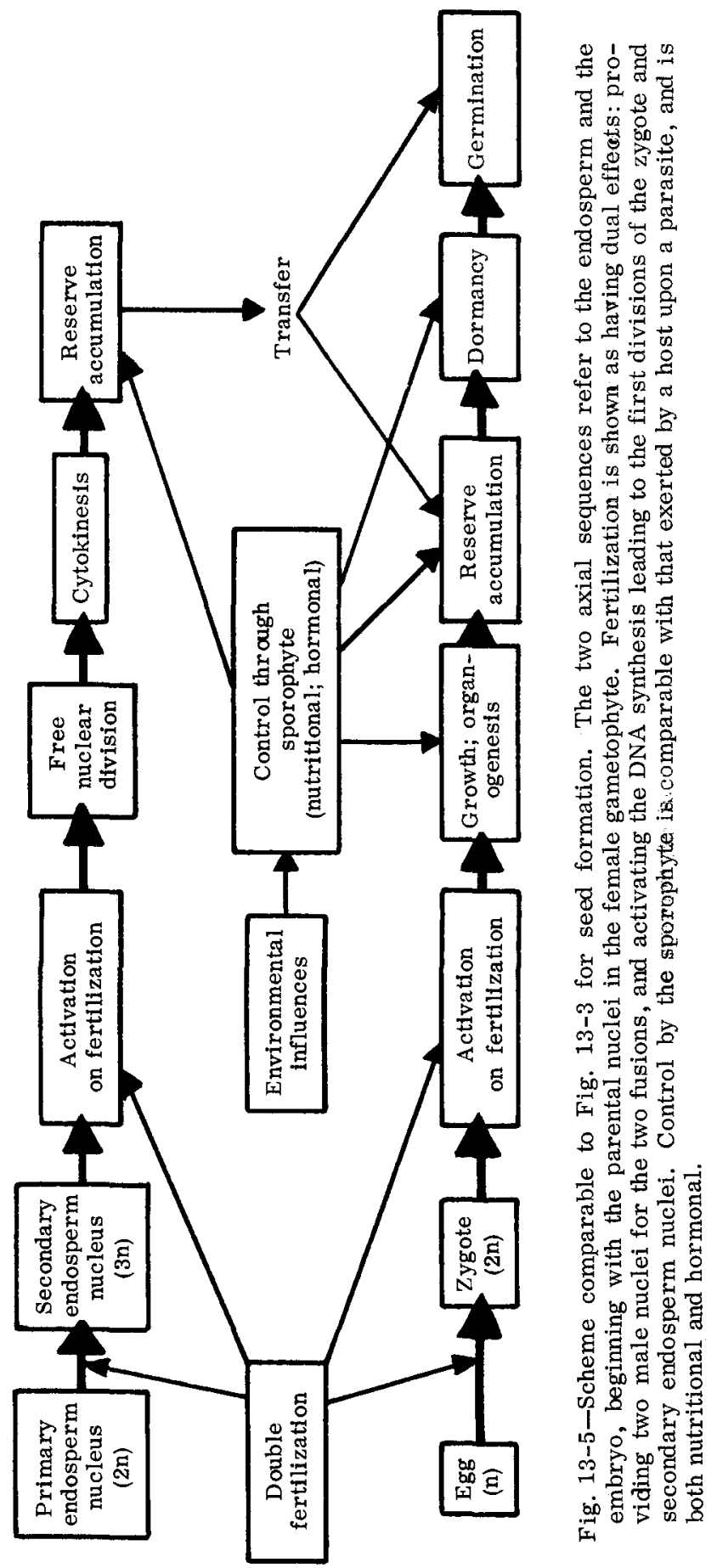


of differentiation and development. A conspicuous example is the absence of any comprehensive explanation for the way environmental influences, particularly photoperiod, affect the transition to flowering. The perceptive mechanism in the leaf patently involves phytochrome, and there are cogent reasons for supposing that there is a transmitted stimulus (Salisbury, 1963; Hillman, 1962; Lang, 1965b). Yet in spite of the great body of data at hand, there is so far no unequivocal indication of its nature, nor of the precise functions other growth substances, notably the gibberellins, discharge in the photoperiodic response (Chailakhyan, 1967, 1968). The physiology of flowering-plant reproduction remains therefore a most challenging field for research, and obviously one of considerable practical importance if we are ever to achieve the ability to manipulate flowering with precision for breeding and production.

Essentially the same comments can be made about the control of tuberization, bulbing, and similar processes. The resemblance between tuberization and flowering in manner of control has been mentioned above. Since the work of Zimmermann and Hitchcock (1936), it has been clear that shoot-generated stimuli pass to the potential tuber sites in subterranean organs, and control by photoperiod and temperature has been adequately demonstrated experimentally (Went, 1957; Chapman, 1958; Madec, 1963; Slater, 1963; Gregory, 1965). As with the flowering stimulus, it is possible that the transmissible agent is nonspecific. Nitsch (1966), for example, has shown that the shoot of Helianthus annuus, a species genetically incapable of tuberization, will nevertheless act as a photoperiodic receptor for a grafted root system of artichoke, Helianthus tuberosus, and transmit the tuber-activating stimulus. Wareing et al. (1967) have reported that tuberization in Solanum andigena, a species setting tubers in short days, can be promoted in long days by foliar sprays of abscisic acid (dormin). These authors suggest that this effect could be an indirect one resulting from retardation of shoot growth, but the possibility remains that the transmissible stimulus is indeed abscisic acid (Nitsch, 1966); if so there is a glimpse of a unifying principle, since tuberization is normally associated with increasing inactivity of vegetative apices. However, the hormonal control system is undoubtedly complex. Abscisic acid depresses levels of endogenous gibberellins in some tissues (Thomas, Wareing, and Robinson, 1965), and exogenous GA3 can inhibit tuberization (Tizio, 1964). During the early period of tuberization there is active cell division and growth, and this suggests cytokinin activity. It is therefore significant that cytokinins have been found in the young potato tuber (Tizio, 1966), and that the tuberization of the artichoke (Cynara scolymus) in vitro is promoted by kinetin (Courduroux, 1966). In the interplay of the different classes of growth substances in natural tuberization, it could be that the effect of the mobile stimulus, should this be abscisic acid, is to change the balance between other physiologically active substances in the target tissue. If so, precise observation of time-related changes in the responding sites will be needed to elucidate the sequence of events and evaluate their meaning for the differentiation of storage tissue and the subsequent passage into dormancy (Burton, 1963). 


\section{The Nutritional Factors}

There is the further question of the part played by nutrients in the control of development and differentiation. Theories current 30 or 40 years ago attributed roles in the control of development to carbon/nitrogen ratios, and correlations can often be observed between measure of nutrient status like this and developmental state. Apart from the problem of what is cause and what effect here, it is now apparent that in so far as the environment does affect flowering, tuberization and other comparable developmental events, it is through specific timekeeping stimuli which do not impinge directly on nutrient status. This conclusion seems in conflict with much earlier work where nitrogen nutrition, in particular, was thought to be an important factor in the control of flowering. Various chapters in The Induction of Flowering, edited by L. T. Evans, shortly to be published, show what is evidently the true situation. In species where the photoperiodic or thermal control of flowering is rather positive, nitrogen nutrition affects initiation very little, but in plants where these controls are less effective, nitrogen status may modify the time of initiation, and does commonly affect the abundance of flowering. Nitrogen availability may be a factor in controlling the balance of vegetative and reproductive growth through its effect on leaf senescence, a point mentioned further below.

Nevertheless, we are not well informed on the specificity of nutritional effects in development. No particular chemical connotations attach to the concept of a hormone, and there are situations where a constituent normally classed as a nutrient fulfills what is essentially a hormonal role. This may be of considerable importance when interrelationships between assimilation, differentiation, and storage are in question. Specificity has certainly been revealed in some experiments and two examples will serve to show that both organogenesis and differentiation at the cellular level may be subject to control by nutrient factors. Sexuality in Arisaema japonica is determined, as in corn, by the activation of carpels or stamens in any one inflorescence and the concomitant suppression of organs of the alternative sex. The plant is perennial, and the sexuality in any one year is closely related to corm size. Below a critical size there is no flowering; above this level, a male inflorescence is formed, and with a yet larger corm there is a transition to femaleness. Cutting the corm so as to reduce the reserves available causes a putatively female inflorescence to differentiate as a male one, or to form flowers of both sexes (Maekawa, 1927). The effect here is undoubtedly teleonomic and it is quite specific. The agency in this example of the control of flower morphogenesis has not been identified, but it is possible that it is the concentration of sucrose in the vicinity of the developing inflorescence. Specific control of cell differentiation by sucrose was demonstrated by Wetmore and Rier (1963), who were able to show that the development of vascular nodules in a block of lilac callus could be controlled by adjusting the balance between an auxin, $\alpha$-naphthalene acetic acid, and sucrose diffusing into the block from a localized source. Jeffs and Northcote (1967) have confirmed 
that the effect of sucrose is indeed highly specific in this system, and have used labelled sucrose and auxin to give quantitative estimates of the relative concentrations required for the induction.

\section{GROWTH, DIFFERENTIATION AND TRANSLOCA TION}

Translocation has been given princely treatment in other contributions to this symposium, and I shall accordingly restrict my remarks to the aspects most closely connected with growth and differentiation. One familiar relationship is seen in the effects of growing structures on the capacity of the transport system. The translocating tissues, xylem and phloem, are themselves the product of cell differentiation, and the establishment of conducting strands is as much subservient to the general developmental controls within the plant as any other histogenic event. In primary growth the tendency is for the demands of an organ to be nicely balanced against the capacity of the conducting channels leading into it, and it has to be supposed that this relationship depends upon the working out of a pre-established program : of cell differentiation, providing for some anticipation of the ultimate requirements of the organ. This is well seen in the differentiation of the leaf, where the number of veins initiated in the primordium is related not to the size of the primordium but to the ultimate area of the lamina.

Demands rising later in life are met by secondary growth in the vascular system, and this is ordinarily effected by cambial activity. The cambium is under hormonal control, and its activities are related to the demands of the remote site because the hormonal flow from that site is related to the growth being accomplished there. The growth of massive fruits presents a model system (Nitsch, 1952). Pollination promotes auxin synthesis in the ovary tissue and ultimately in the developing seeds, and in consequence of the enhanced auxin flow through the pedicel, the growth of vascular tissue is promoted. This in turn facilitates the flow of water and nutrients into the fruit, and increases its competitive power in relation to other organs of the plant. There can thus be a kind of positive feed-back loop operating through control of the capacity of the translocation system. There are similar effects in the development of vegetative storage organs, and the control pathway is indicated in Fig. 13-3.

Growing tissues have also more immediate effects on transport. Loomis (1953) drew special attention to the sequestering effect developing storage structures have on assimilates, and Aronoff (1955), commenting on the movement of ${ }^{14} \mathrm{C}$-labelled photosynthate, concluded that no physiological condition approaches growth as a causative agent for the direction and magnitude of translocation. Some recent observations cast light on the nature of the influence that meristematic and growing tissues have on the movement of nutrients and metabolites. It is usual to look upon the translocation stream as a flow of materials between source and sink, and it has been widely accepted that the gradient is maintained by the continuous removal of compounds at the receiving end by incorporation into insoluble fractions in the cells. However, some evidence now indicates that the conducting system itself actively 
directs assimilates into the growing zones, and that the process is under hormonal control (Kursanov, 1963, Edelman, 1963). The striking experiments of Mothes and collaborators (Mothes, 1964) show that accumulation and retention need not only be due to consumption of the translocated compounds. When the synthetic cytokinin, kinetin, is applied in a spot on one-half of the lamina of a detached tobacco leaf (Nicotiana tabacum L.), amino acids and other substances move to the site of application, and are held there. This is true even for amino acids which are not incorporated into protein; these accumulate in soluble state at the kinetin site. The applied kinetin does promote synthesis and retard senescence, but this effect can be separated from that on transport, since RNA and protein synthesis can be blocked with inhibitors without preventing the movement of metabolites to the kinetintreated area. In pointing out that these cytokinin effects must involve a form of "active" transport since movement can occur against a gradient of a soluble substance, Mothes suggests that the key lies in a change in the capacity of the receiving cells to capture and retain low molecular weight substances and to prevent their rediffusion. This interpretation accepts the proposition that the intensity and direction of movement depend on the capacity and location of the sink. However, the experiments of Pozsár and Király (1964) permit a different conclusion-namely that the effect is on the transport system itself. In intact plants of Phaseolus vulgaris, the movement of labelled phosphate, glucose, and cysteine from a site of application on an old leaf was principally to the growing point and the younger leaves. When the excised bud was replaced by a kinetin source, the normal pattern of movement was restored, and upper leaves became receptors. Here there is no question of competitive growth at the cytokinin site because the accumulation was measured in adjacent leaves. This effect is evidently one on the polarity and activity of the conducting tissues.

In some systems, auxins reveal what is evidently a similar capacity to direct translocation. Loomis (1953) pointed to the possibility that the auxins of developing seeds may be concerned in their capacity for inducing movement of metabolites, and Booth et al. (1962), Davies and Wareing (1965), and Wareing and Seth (1967) have described experiments in which applied auxins produce effects on movement of nutrients very like those recorded for cytokinins. Indeed, Wareing and Seth (1967) record that IAA applied to the cut peduncle of Phaseolus vulgaris after removal of the developing fruit induced a greater movement of ${ }^{32} \mathrm{P}$ as phosphate into the peduncle stump than either kinetin or gibberellic acid. The most effective treatment in these experiments was the application of IAA, gibberellic acid and kinetin together, when the movement was more than four times that induced by IAA alone. This suggests that any one of the three classes of compound would stimulate movement when applied exogenously were its natural counterpart to be at a relative minimum in the tissue.

The implications of these results for future study of the movement of translocated materials into storage structures is indeed far-reaching. As Mothes has said, kinetin in his experimental systems is a model for those substances which cause storage organs to fill in the natural growth of the plant; and the natural cytokinin, zeatin, offers an even better 
model (Engelbrecht, 1967). It cannot be fortuitous that compounds having the capacity to provoke cell prolifer ation in undifferentiated tissues and to induce growth in dormant buds-and known also to be concerned in the growth of seeds and fruits and other storage organs-should also have specific effects on translocation.

\section{DIFFERENTIA TION AND THE COMPONENTS OF YIELD}

My purpose in this section is to consider some of the practical implications of the facts, ideas and speculations of the foregoing paragraphs, albeit very briefly and inadequately, taking into account the scope of the topic. We may begin with the commonplace proposition that yield in a crop plant is related both to total assimilation and nutrient uptake achieved during a growing season and to the way the material acquired is partitioned between harvestable storage structures and the rest of the plant. This directs attention immediately to the possibility that where the differentiation of storage structures is an alternative to vegetative growth the timing of the transition from one to the other will be a factor in determining yield, and the certainty that such factors will be found among those governing the numbers of storage structures and their competitive ability in the accumulation of reserves.

In plants like the cereals with terminal inflorescences, vegetative growth and flowering are strictly alternative processes in any one axis. The timing of the translation of the apex in terms of plastochrons is governed by autonomous controls, modulated by inductively-acting environmental factors such as temperature and photoperiod. It is evident, then, that in so far as assimilatory capacity is related to the number of foliage leaves it will be influenced by the developmental controis concerned with the transition to flowering. How far this will ever be a limiting factor will depend upon other circumstances, including leaf area duration and net assimilation rate. Furthermore, it is now well established that foliage below the flag leaf makes little contribution to grain yield in barley (Hordeum vulgare L.) and wheat (Triticum aestivum L.) (Archbold, 1942; Buttrose and May, 1959; Thorne, 1963, 1965; Kriedemann, 1966), and similarly in corn the contribution of the upper leaves considerably exceeds that of the lower (Allison and Watson, 1966). It would seem, then, that numbers of leaf-bearing nodes is not a highly importantfactor in itself in cereals, and accordingly that little practical significance attaches to this aspect of the functioning of developmental controls concerned in the transition to flowering. The time of initiation may, however, have some importance, should the correlations of yield with leaf area duration after the beginning of grain development revealed in small-grain cereal experiments (Watson, Thorne, and French, 1963; Welbank, French, and Witts, 1966) prevail with wide variation in relative periods of vegetative and reproductive activity at the apex.

Another component of yield in cereals is the ability of the developing grain to accept assimilate, a factor related both to grain number and individual capacity. Most investigations have shown number of grains set to be a major factor, indeed sometimes a limiting one (Bingham, 1967; Moss, 1962; Asana and Williams, 1965; Nösberger and 
Thorne, 1965; Allison and Watson, 1966). If this be indeed a general condition, the circumstances affecting grain set are crucially concerned with yield.

For cereals in general, failure of grain set due to lack of pollination is rarely important, both because of the widespread occurrence of selfing and the abundance of pollen available in the crop. The limitation of grain number is imposed during ear initiation by the numbers of plastochron cycles executed, and in the small grains by the numbers of earproducing tillers and in corn by the number of axillary ear-shoots beginning development. Taking firstly the matter of inflorescence size, it is pertinent to enquire whether the number of spikelet primordia defined before growth at the apex ceases is governed absolutely by influences effective before initiation, or whether the circumstances prevailing during the early growth of the inflorescence determine its ultimate size (Ryle, 1966). The question concerns another facet of the control of metamerism discussed above. In cereals, as in most species, there is a sharp decrease in the plastochron with inflorescence initiation. Thereafter the number of nodes, and accordingly of spikelet primordia defined, is given by the duration of growth divided by the new plastochron. Ryle (1965) found that daylength experienced before initiation of the inflorescence determined spikelet number in Lolium perenne, a quantitative long-day species, short days increasing the number of primordia formed. A similar response was observed in wheat by Thorne, Ford, and Watson (1968). In corn, a quantitative short-day species, long days experienced before inflorescence initiation increase floret number both in terminal male and lateral female inflorescences (Moss and HeslopHarrison, 1968). The daylength effect here is specifically a photoperiodic one, since it was observed in night-interruption experiments when the effective energy content of long and short days was the same. Comparable results exist for other species, sufficient probably to support the generalization that daylength conditions delaying inflorescence initiation increase primordium number.

There is no doubt, however, that the photoperiodic effect is confounded with a nutritional one in the normal growth of the plant. In corn, long photosynthetic days are more effective than photoperiodicallyeffective long days given by night interruption (Moss and HeslopHarrison, 1968) in enhancing the number of female florets formed. Ryle (1963) similarly concluded that although shoot age at the time of initiation was a primary determinant of ear length in Phleum pratense, nutritional factors. acting before initiation, including both mineral and carbohydrate availability, affect final inflorescence size, and the same author (1967) noted a marked effect of light intensity during inflorescence development on floret number in the spike of Lolium perenne and on branch and floret number in the panicle of Festuca pratensis. In this symposium, Dr. Murata (see Chapter 11, this book) has mentioned the effects nitrogen nutrition may have on spikelet number in rice during certain developmental periods.

Nevertheless, for many species with determinate spicate inflorescences like the cereals, potential inflorescence size in normal light and nutritional conditions would seem to be established for all practical purposes before the actual translation of the apex. This must mean that 
where the potential yield ceiling is governed by grain number, this too is setbefore the beginning of flowering. Conditions after initiation may act to lower fertility by causing floret abortion, but never to raise it by inducing a resumption of spike extension (Heslop-Harrison, 1961; Thorne, Ford, and Watson, 1968). This would seem to. be an important conclusion, and for this reason some effort should be devoted to reinforcing and generalizing it and to the further analysis of the relative importance of developmental and nutritional controls in the preinitiation period.

The other factor contributing to grain set per plant is the number of contributing inflorescences. In the small grain cereals this is determined by tillering; in corn by the number of potential ear sites activated. Here again the evidence shows that the ultimate potential is governed by determinations made early in the life of the plant. For the small grain cereals no generalizations beyond this seem yet feasible, because of the complexity of temperature, daylength, and nutritional interactions, and the existence of species and varietal differences (Aspinall, 1961; Friend, 1965; Thorne, Ford, and Watson, 1968). There is also here the problem of competitive effects between tiller initials, and in regard to yield in a field crop the significance of tillering has to be considered in relation to plant density (Thorne, 1966). With corn, on the other hand, where the ear is a condensed lateral structure, modifying ear number is not a matter of altering the number of complete foliated axes, but rather of changing the number and distribution of assimilate sinks on the one axis. Ear primordia are initiated at many successive nodes, yet in most cultivars all but one or two fail to develop and then abort. One may note that the archaeology of corn shows that man has willed it to be like this, through selection for cob size and the concomitant changes in plant architecture this has brought about (Mangelsdorf, MacNeish, and Galinat, 1964). The activation of some primordia and the decisive suppression of others takes place early in development, although probably not immediately after inception. There is a photoperiodic element in the control, long days increasing the number of ears developing (Moss and Heslop-Harrison, 1968), and probably a less specific nutritional element (e.g., Andrew, 1967). The suppression of the supernumerary axillary inflorescences has some of the characteristics of correlative bud inhibition, and growth can be provoked by removing competing inflorescences if the excision is made at an early enough stage; yet, later in development, the suppression becomes irreversible (some aspects of the competition between inflorescences have been considered by Moss, 1962). There is an obvious invitation here for fuller investigation, since it should not be too difficult to discover more about the factors controlling the relative activity of the ear primordia, and to explore the possibility of control of inflorescence number by chemical means. Furthermore, it is evident that this particular characteristic of the corn plant would yield readily to manipulation by breeding, reversing the trend hitherto under domestication. This might be one way to alleviate any limitation of yield due to lack of grain capacity, and there are other reasons for rethinking the corn plant along these lines (Army and Greer, 1967).

In systematically-flowering species grown for fruit or seed and in 
plants producing vegetative storage organs, storage and vegetative growth are competing rather than alternative processes. The great diversity of crop plants in these categories prevents generalization, but again a principle of wide validity is that the distribution of resources during the main period of assimilation is according to a program determined quite early during growth, largely by photoperiod and temperature. These factors may govern not only the timing and localization of flowering and storage-organ inception, but also the competitive ability of apical buds.

A recession in shoot growth is a common concomitant of the beginning of tuberization (Milthorpe, 1963), and in part this reflects competition for assimilate. However, the more specific developmental control is revealed by experiments like those of Nösberger and Humphries (1965) with the potato (see also Goodwin, 1963). When tubers were removed during the filling period, some apices responded by a resumption of growth, but others remained inhibited. These potential sinks were never reactivated, even although a high credit balance of carbohydrate was established in the shoot. Comparable observations have been made with other tuberizing species; for example, in the Jerusalem artichoke short days induce tuberization and stop shoot growth, and thereafter the apical bud remains firmly inhibited, even if the tubers are removed (Edelman, 1963).

These findings have to be considered in relation to the general phenomena of bud inhibition and apical dominance-phenomena, unfortunately, not yetfully understood. While the nutritional status of the shoot does affect the strength of apical dominance-as revealed, inter alia, by the experiments of Gregory and Veale (1957) on flax (Linum usitatissimum)-the control is mediated through the hormonal milieu of the plant. The classical view attributes control to the auxin stream from the dominant apex (Thimann and Skoog, 1934), and recent work on the effects of exogenously supplied kinetin on lateral bud inhibition in peas has led to the proposition that it is the interaction of auxins from this source and the natural cytokinins at the bud site that determines whether growth will occur or not (Wickson and Thimann, 1958). Among other factors to be taken into consideration are the effects on the nutrient status and capacity for growth of the differentiation of vascular tissue at the bud base (Audus, 1959), and the important possibility that correlative bud inhibition, like bud dormancy, may depend upon inhibitors (Wareing et al., 1967). Dörffling $(1966,1967)$ has shown that inhibitors are present in lateral buds of pea suppressed by apical dominance, and has demonstrated the existence of abscisic acid in this plant. It would seem very likely, then, that at least three hormonal factors interact in the control of bud dormancy. It may be that the tuberization response in the potato is but one part of a syndrome of effects arising from an increase of abscisic acid levels in inductive environments-taking into account the findings of Wareing et al. (1967)-others being the suppression of shoot growth and the reinforcement of the correlative inhibition of lateral buds.

This would mean that the partitioning of assimilate and nutrients between aerial parts and tubers is not governed simply by competition between two sites with the shoot system gradually losing, but by a reg- 
ulated shift of growth activity related to an innate developmental program, itself keyed to time-keeping agencies in the environment. The existence of some form of teleonomic control even over the relative growth rates of tubers of the same potato plant is shown by the work of Moorby (1968). According to Moorby, the tubers grow in turn, each receiving the greater part of the available substrate during its active periods. There is no indication that tubers at particular sites gain and retain growth advantage, as might be expected were there to be severe competition. The observed phasing could be due, as suggested by Moorby, to the tubers possessing different sources of assimilate supply, but it may also be interpreted as further evidence of the working out of a hormone-mediated developmental program.

The preceding discussion has been mainly focussed upon the relationships between vegetative growth and storage-structure formation; but there is still another factor to be considered, the influence of reproduction, tuberization and similar activities on the photosynthetic capacities of the mature parts of the plant. Two aspects of this concern the longevity of leaves and direct effects of assimilate "sinks" on net assimilation rate.

It has long been appreciated that the initiation of storage structures, whether related to sexual reproduction or perennation, not only reduces shoot growth, but accelerates leaf senescence (Murneek, 1926; Milthorpe, 1963). The trend can be slowed, or even reversed, by removal of the storage structures. Walkley (1940) showed that barley leaves which had lost up to half of their protein content could be induced to resume protein synthesis by removing the upper part of the shoot, and Wareing and Seth (1967) have similarly recorded that removal of the seed from the developing pods of Phaseolus vulgaris not only delays loss of chlorophyll and protein from the leaves but causes a substantial rise in these constituents over control levels for a period of 5 or 6 weeks. Again it might be asked whether effects like these are essentially aspects of competition (Molisch, 1938), or whether the senescence is a controlled event, representing yet another manifestation of the working out of a genetically determined developmental program, as envisaged by Leopold (1961). It is noteworthy that the latter view was supported by most of the authors who touched on the topic in the 1967 symposium of the Society for Experimental Biology on the biology of aging.

Annual and biennial crop plants show the type of senescence Osborne (1962) or (1967) has termed sequential, the older leaves senescing first. Discussing possible explanation of this kind of leaf aging, Simon (1967) stated the view that the principal factor is the rate of translocation of metabolites, particularly amino acids, from the leaf. The argument is that a fraction of the leaf protein is turning over, so that a drain of amino acids would lower the available pool for resynthesis, resulting in a progressive net loss of protein from the leaf. This would mean that control over leaf senescence resides mainly in the factors determining the direction and magnitude of the translocation of nitrogenous and other metabolites in the plant. Since it implies that the nitrogen pool could be a limiting factor, it also offers an explanation for the effects of high nitrogen nutrition in extending leaf life. 
An alternative possibility considered by Simon (1967) was that leaf senescence is due to a decay in protein synthesis through the cessation or reduction of mRNA production (Osborne, 1962). The experiments of Mothes' group mentioned above indicate that both of these explanations are likely to be correct. Cytokinins like kinetin not only redirect the flow of amino acids in the leaves, but enhance RNA and protein synthesis at the site of application. According to Wollgiehn $(1965,1967)$ all RNA fractions increase in kinetin-treated tobacco leaves, including a rapidly labelled fraction with some characteristics of mRNA. Similar observations have been made by Carpenter and Cherry (1966) for the cytokinin, benzyladenine, applied to peanut cotyledons, and Osborne (1967) has shown that the action of kinetin in delaying leaf-senescence in Xanthium involves an actinomycin-D sensitive RNA synthesis.

These observations have led to the hypothesis that natural control resides in cytokinins. It has been suggested that cytokinins from the the root system act as leaf hormones (Wareing and Seth, 1967; Wollgiehm, 1967), and that the effect of competing fruits, seeds and other storage structures may be to divert these from the leaves, so promoting premature senescence. However, no overall explanation can yet be given for the control of leaf senescence, since in no species have all the interactions between hormonal, or quasi-hormonal, factors been worked out. Various synthetic auxins simulate the cytokinin effect by maintaining greenness in leaf tissues, and Osborne (1967) has offered a scheme according to which leaf cells in treated areas induce senescence in neighboring cells by stimulating the formation of a senescence factor. She has indicated further that abscisic acid possesses some of the properties postulated for this factor (see also Wareing et al., 1967). This does not exhaust all the possibilities, since a role for ethylene in leaf senescence is suggested by the work of Burg and Burg $(1966,1968)$, and it is a moot point where gibberellins, known to affect leaf growth (Humphries and Wheeler, 1963) fit into the picture.

The possible practical significance of leaf senescence naturally lies in the effect loss of metabolic activity in the leaf may have on the availability. of assimilate for growing storage structures. The conclusion from cereal experiments such as those of Watson, Thorne, and French (1963) already mentioned has been that yield is closely correlated with leaf area duration after the beginning of grain development. Leaf area duration is related to leaf initiation, growth in area and senescence. Since in cereals leaf initiation is terminated in any one axis at the time of flowering, and since the final leaf area is fixed soon after, the time of leaf senescence is the main determinant of leaf area duration after flowering. Nutritional manipulation. particularly affecting nitrogen availability, can delay leaf senescence, but there is the further question whether any advantage would lie in attempting to extend leaflife by chemical means. This is problematical. After their photosynthetic function is complete, leaves are drawn upon by storage structures for metabolites other than carbohydrates; for example, for the amino acids released by protein breakdown. It may be that in the evolution of each species a compromise has been achieved between these two roles of leaves, and that to disturb this by delaying senescence and protein breakdown would destroy the adjustment of the growth pattern to the 
seasonal cycle. Yet for a cultivated species where ecological adjustment is not necessarily an over-riding consideration one might contemplate protracting the photosynthetic function of leaves, taking as a "penalty" a higher retention of leaf protein and minerals at the end of the growing season. But the chain of effects leading from delayed senescence could be far-reaching, and lead to disastrous consequences even in cultivated species. If the leaves are the source of controlling signals for events later in the lives of storage structures and seedsfor example, in the imposition of dormancy-radical alteration of the aging process in leaves could upset this coordination. In the potato, were the leaves to remain exporters of gibberellins, there is no doubt that the normal processes of tuber maturation would be upset (Claver, 1960).

We come to another somewhat equivocal area in turning to the ef fects of storage structure-growth on net assimilation rate. The commonpattern in observations in many experiments has been that removal of developing storage organs-seeds, fruits, tubers-leads to a fall in net assimilation rate (e.g., for cereals, Kiesselbach, 1948; Moss, 1962; for fruits, Maggs, 1963; for tubers, Burt, 1964; Nösberger and Humphries, 1965), and this has been taken to mean that size of the sink for photosynthate may in some conditions determine photosynthetic rate. This view has been supported by the demonstration that net assimilation rate increases in spinach beet tops (Beta sp.) when they are grafted on to sugar beet roots (Beta vulgaris L.) (Thorne and Evans, 1964), and Humphries (1963) has argued that the increased photosynthesis observed in detached leaves when roots differentiate from the petiolepoints in the same direction. Some experiments do not seem to have shown an effect of sink size on net assimilation rate, however; thus Nösberger and Thorne (1965) found that removing florets had little effect on photosynthetic rate in barley, although it did increase leaf area and greatly modified the movement of carbohydrate.

Evidently there could be several explanations for the results of experiments where sink size does seem to influence net assimilation rates. The formation of roots from the petioles of detached leaves retards leaf senescence, and enhances DNA, RNA and protein synthesis, evidently largely in the plastids (Böttger and Wollgiehn, 1958). In this case the increase of net assimilation rate accompanying rooting could be due to rejuvenation and enlargement of the photosynthetic apparatus. The effect $c$ an be mimicked with cytokinins, and for this reason it has been supposed that the leaf rejuvenation is due to the flow of a cytokininlike hormone from the new roots (Böttger and Lüdemann, 1964).

The situation would seem to be quite different where the presence of storage organs seems to maintain a certain net assimilation rate which diminishes upon their excision. As we have seen, removal of storage structures can retard leaf senescence; it acts, then, like root development on the detached leaf. Yet photosynthetic efficiency is apparently lowered, not enhanced. Since the surplus carbohydrate accumulates in stems and leaves (corn, Moss, 1962; potato, Nösberger and Humphries, 1965), the effect here may be a direct one on the photosynthetic carbon pathway (Went and Engelsberg, 1946).

Considering the overall picture, the many interactions between leaf 
and storage structure would seem to point to the presence of several compromises; and others are apparent when the relationships between shoot and root (not discussed here) are taken into account (Loomis, 1935). Beyond the compromise mentioned above between the different roles of leaves, in some species yet a further balance must be achieved between the leaf-senescence inducing effect of storage-structure differentiation and the influence these structures have on photosynthetic efficiency. Stated tersely, the circumstance of grain or tuber set may be regarded as ensuring that leaves have a short life but an active one. Again, this is only to be expected as consequence of the selective molding of the developmental cycle to the march of the seasons. It would be quite wrong to suppose that the network of reciprocally-acting controls linking the different parts of the plant has any appreciable accidental element-that, for example, the effect of storage organs on leaf efficiency or senescence is just some sort of mischance unavoidable for some obscure physiological reason. There will undoubtedly be real adaptive advantage to these relationships where they exist-probably along the lines mentioned above, namely that the leaves are not only sources of photosynthate, but convenient reservoirs from which mineral nutrients can be withdrawn at appropriate times during the growth of perennating organs and seeds. This argument does not imply that the adjustments are always perfect; patently they are not. It does mean, however, that in plants in general the genetic control of the whole system of interactions is likely always to be quite flexible, otherwise adaptation to different lengths of growing season would never have been possible. The genetic basis probably always lies in polygenic systems, or in some other mechanism permitting quantitative gradation, such as the serial replication of cistrons. The implication of this in turn is that it should be within the capacity of man to adjust, through breeding, any part of the control network, and so to tailor whatever pattern of developmental cycle he should wish.

\section{THE OUTLOOK}

I began this review by commenting on the wide gaps in our knowledge of the control of differentiational and developmental processes in plants, and the point will have been underlined by a great deal of what I have said in the preceding paragraphs. Yet much of the phenomenology must be regarded as being tolerably well understood. Certainly this is true of many kinds of environmental response, and notwithstanding the complex and confusing situation with endogenous hormones, there is now a very substantial mass of reliable information concerning plant responses to chemical and other treatments affecting development.

There is a continuing challenge to apply this knowledge in the search for increased yield and production efficiency. In a sense, of course, much of crop husbandry is already concerned with the manipulation of plant development for these ends, but in the present context the problem refers more pertinently to the use of knowledge about the ways patterns of growth are governed in plants to take control yet more completely into human hands. As a botanist I am very reluctant to 
speculate much on this matter in the presence of so many distinguished agronomists, even although my brief contained an injunction to do so. Still, a comment or two may be admissible. There is no doubt that in the generality of cases the most effective way to obtain a growth pattern efficient in a given environment for a particular purpose is to breed a genotype for the job, but there is no shortage of examples of deliberate manipulation of development in field crops to achieve like ends. The most massive operation was probably grain vernalization in Russia, and no one can have failed to have been impressed by what we have heard here from Dr. H. F. Clements (see Chapter 14, this book) concerning the precise and skillful programming of development practiced with the pineapple and sugar cane crops in Hawaii. Contemplating these trends and those to be seen in horticulture, it seems certain that the manipulation of development in field crops by chemical and other means will become increasingly important in the future. One obstacle is the practical difficulty of regulating treatments on the scale required and fitting them to different climatic contexts and the vagaries of the weather. Yet, again, the trend already seen in disease and weed control and in nutrition towards more and more precise regulation of treatments is indicative. It may not be too long before it becomes feasible to apply on a field scale complicated manipulative procedures which can now be managed only in controlled environments or small experimental plots. In any event, it would seem mistaken to plan on the assumption that this could never become possible however much ingenuity were to be applied. In the long run, the real problem probably concerns the desirability of this kind of intervention rather than the practicability. Judgments on this will require very much more knowledge about the detailed nature of developmental limitations to yield in the major crop plants and about the ways they can be alleviated.

For the immediate future, it seems evident that it is in the realm of plant breeding that the greatest rewards from new knowledge of developmental processes in plants are to be found. Breeding plants for the future is being treated in other contributions, and I am relieved of the need for extensive comment here. However, I would emphasize one point that has become obvious now: whereas hitherto much breeding has perforce taken as a measure of progress the attainment of yield itself, a new approach has opened up where knowledge of the components of yield is permitting a more rational and direct attack on individual limiting factors (Bell and Kirby, 1966). Developmental plant physiology is likely to have an increasing contribution to make here, since many of these limiting factors will undoubtedly turn out to be concerned one way or another with differentiation and development.

It is perhaps unnecessary to stress the contribution to breeding technique physiological manipulation can make: for some 40 years now advantage has been taken of the control available over developmental periodicity through temperature and photoperiod in the breeding of crops ranging from sugar beet to fruit trees. But some comment is due concerning the increasing openings in breeding work for the application of chemical means of manipulating differentiation and morphogenesis. Some remarkable examples are already available, such as the production of gynoecious cucumber lines by Peterson (Peterson and Ahnders, 
1960; Peterson, 1960). Here the fact that sex expression can be regulated by manipulating the auxin-gibberellin balance was pressed into service to breed for extreme femaleness, pollen being induced in female individuals when required for a cross by treatment with endogeous gibberellin. With increasing knowledge of the ways flowering, sex expression, and pollen fertility can be influenced chemically, there is a real hope that many of the serious practical problems of breeding work can be reduced or eliminated altogether, and the hazards and tedium of such routine tasks as emasculation removed. Similarly, impediments to breeding arising from intra- and interspecific incompatibility and embryo-endosperm disharmony should become less significant as it becomes possible to control the detailed events of reproduction more and more effectively. I do not think it is pressing the point too far to suggest that one of the vital yet time-consuming tasks of breeding, final seed multiplication, could be revolutionized by the development of methods of mass cloning of desirable genotypes using dissociated-cell technique. The way has already been marked out by Steward and his collaborators (e.g., Steward et al., 1964) with the carrot (Daucus carota L.). On appropriate media in culture, isolated cells of the carrot seedling will differentiate embryoids, each of which has the potentiality of developing into a plant. So far the method has met with success with umbelliferous species, but there is no reason to suspect any basic taxonomic limitation on the technique. Tissue culture may prove to be of great value to plant breeding in other ways; Nitsch and Nitsch (1969), for example, have shown how haploid plants can be derived in great numbers from the pollen grains of Nicotiana species. Should the method prove widely applicable, it has the makings of a practical tool for obtaining one-step homozygosity, since colchicine already offers a method for producing polyhaploids.

\section{LITERATURE CITED}

Allison, J. C.S., and D. J. Watson. 1966. The production and distribution of dry matter in maize after flowering. Ann. Bot. 30:365-382.

d'Amato, F. 1964. Endopolyploidy as a factor in plant tissue development. Caryologia 17:41-52.

Andrew, R.H. 1967. Influence of season, population and spacing on axillary bud development of sweet corn. Agron. J. 59:355-358.

Arber, A. 1934. The Gramineae. Cambridge University Press, New York.

Archbold, H. K. 1942. Physiological studies in plant nutrition. XIII Experiments with barley on defoliation and shading of the ear in relation to sugar metabolism. Ann. Bot. 6:487-531.

Armstrong, D. J. 1966. Hypothesis concerning the mechanism of auxin action. Proc. Nat. Acd. Sci. USA 56:64-66.

Army, T. J., and F. A. Greer. 1967. Photosynthesis and crop production systems, p. 321-332 In A. San Pietro, F. A. Greer and J. J. Army (ed.) Harvesting the sun. Academic Press, New York and London.

Aronoff, S. 1955. Translocation from soybean leaves. Plant Physiol. 30:184-185.

Asana, R. D. and R. F. Williams. 1965. The effect of temperature stress on grain development in wheat. Aust. J. Agr. Res. 16:1-13.

Aspinall, D. 1961. The control of tillering in the barley plant. I. The pattern of tillering and its relation to nutrient supply. Aust. J. Biol. Sci. 14:493-505.

Audus, L. J. 1959. Correlations. J. Linn. Soc. Bot. 56:177-187. 
Badenhuizen, N. P. 1958. Structure, properties and growth of starch granules. Encyclopedia of plant physiology 6:137-153.

Bell, G. D. H., and E. J. Kirby. 1966. Utilization of growth responses in breeding new varieties of cereals, p. 308-319. In F. L. Milthorpe and J. D. Ivins (ed.) The growth of cereals and grasses. Butterworths, London.

Bingham, J. 1967. Investigations on the physiology of yield in winter wheat, by comparisons of varieties and by artificial variation in grain number per ear. J. Agr. Sci. Cambridge 68:411-422.

Bonner, J. 1965. The template activity of chromatin. J. Cell. Physiol. 66:77-90.

Booth, A., J. Moorby, C. R. Davies, H. Jones and P. F. Wareing. 1962. Effects of indolyl-3-acetic acid in the movement of nutrients within plants. Nature $194: 204-205$.

Bottger, I. and I. Ludemann. 1964. Uber die Bildung einer stoffwechsel-aktiven Ribonucleinsaurefraktion in isolierten Blattern von Euphorbia pulcherrima zu Beginn den Wur zel-regeneration. Flora 155:331-340.

Bottger, I. and R. Wollgiehn. 1958. Untersuchungen uber den Zusammenhang zwischen Nucleinsaure-und Eiweissstoffwechsel in grunen Blattern hoheren Pflanzen. Flora 146:302-315.

Burg, S. P. 1968. Ethylene, plant senescence, and abscission. Plant Physiol. 43:1503-1511.

Burg, S. P., and E. A. Burg. 1966. The interaction between auxin and ethylene and its role in plant growth. Proc. Nat. Acad. Sci. USA 55:262-266.

Burt. R. L. 1964. Carbohydrate utilization as a factor in plant growth. Aust. J. Biol. Sci. 17:867-877.

Burton, W. G. 1963. Concepts and mechanisms of dormancy, p. 17-23. In J. D. Ivins and F. L. Milthorpe (ed.) The growth of the potato. Butterworths, London.

Buttrose, M. S., and L. H. May. 1959. Physiology of the cereal grain. I. The source of carbon for the developing barley kernel. Aust. J. Biol. Sci. 12:40-52.

Carpenter, W. J. G., and J. H. Cherry. 1966. Effects of benzyladenine on accuulation of ${ }^{32} \mathrm{P}$ into nucleic acids of peanut cotyledons. Biochim. Biophys. Acta $114: 640-642$.

Chailakhyan, M. K. 1967. The role of gibberellins in photoperiodism and vernalisation processes of plants, p. 569-576. In Wachstumsregulatoren bei Pflanzen. Gustav Fischer Verlag, Jena.

Chailakhyan, M. K. 1968. Internal factors of plant flowering. Ann. Rev. Plant Physiol. 19:1-36.

Chapman, H. W. 1958. Tuberisation in the potato plant. Physiol. Plant. 11:215224.

Chen, D., S. Sarid, E. Katchalski. 1968. Studies on the nature of messenger RNA in germinating wheat embryos. Proc. Nat. Acad. Sci. US 60:902-909.

Claver, F. K. 1960. Efetos del acido giberelico y de la hidrazida maleica sobre la tuberizacion de la papa. Phyton 15:29-35.

Cline, A. L. and R. M. Bock. 1966. Translational control of gene expression. Cold Spring Harb. Symp. Quant. Biol. 31:321-334.

Courdurox, J. C. 1966. Le mechanisme de la tuberisation chez le topinambour. Bull. Soc. Franc. Physiol. Veget. 12:213-232.

Cutter, E. 1965. Recent experimental studies of the shoot apex and shoot morphogenesis. Bot. Rev. 31:7-113.

Davies, C. R. and P. F. Wareing. 1965. Auxin directed transport of radiophosphorus in stems. Planta 65:139-156.

Dorffling, K. 1966. Weitere Untersuchungen uber korrelative Knospenhemmung. Planta 70:257-274.

Dorffling, K. 1967. Blattfallbeschleunigende Eigenschaft zweier "Hemmstoffe" aus Erbsenpflanzen. Nachweis von (+)-Abszisin II (Dormin), p. 673-674. In Wachstumsregulatoren bei Pflanzen. Gustav Fischer Verlag, Jena.

Edelman, J. 1963. Physiological and environmental aspects of carbohydrate metabolism during tuber growth, p. 135-147. In J. D. Ivins and F. L. Milthorpe (ed.) The growth of the potato. Butterworths, London. 
Engelbrecht, L. 1967. Die Bedeutung vershiedener Cytokinine fur die Uberwindung der apikaler Dominanze bei Nicotiana glauca, p. 647-649. In Wachstumsregulatoren bei Pflanzen. Gustav Fischer Verlag, Jena.

Evans, L. T. 1964. Inflorescence initiation in Lolium temulentum L. VI. Effects of some inhibitors of nucleic acid, protein and steroid biosynthesis. Aust. J. Biol. Sci. 17:24-35.

Friend, D. J. C. 1965. Tillering and leaf production in wheat as affected by temperature and light intensity. Can. J. Bot. 43:345-353.

Galinat,W.C. 1959. The phytomer in relation to floral homologies in the American Maydeae. Bot. Mus. Leafl. Harvard Univ. 19:1-32.

Galun, E., Y. Jung, and A. Lang. 1962. Culture and sex modification of male cucumber buds in vitro. Nature 194:596-598.

Goodwin, P. B. $19 \overline{63}$. Mechanism and significance of apical dominance in the potato. In J. D. Ivins and F. L. Milthorpe (ed.) The growth of the potato, Butterworths, London.

Gregory, F. G., and J. A. Veale. 1957. A re-assessment of the problem of apical dominance. Soc. Exp. Biol. Symp. 11:1-20.

Gregory, E. E. 1965. Physiology of tuberisation in plants. Encyclopedia of Plant Physiology 15:1328-1354.

Helgeson, J. 1968. The cytokinins. Science 161:974-981.

Heslop-Harrison, J. 1961. The experimental control of sexuality and inflorescence structure in Zea mays. Proc. Linn. Soc. 172 Session: 108-123.

Heslop-Harrison, J. 1963. Sex expression in plants. Brookhaven Symp. in Biol. 14:109-122.

Heslop-Harrison, J. 1967. Differentiation. Ann. Rev. Plant Physiol. 18:325-348.

Heslop-Harrison, J. 1969. The state of the apex and the response to induction in Cannabis sativa. In G. Bernier (ed.) Cellular and molecular aspects of floral induction. (In press)

Hillman, W. S. 1962. The physiology of flowering. Holt, Rinehart \& Winston, New York.

Hotta, Y., and H. Stern. 1965. Inducibility of thymidine kinase as a function of interphase stage. J. Cell. Biol. 25:99-108.

Humphries, E. C. 1963. Dependence of net assimilation rate on root growth of isolated leaves. Ann. Bot. 27:175-182.

Humphries, E. C., and A. W. Wheeler. 1963. The physiology of leaf growth. Ann. Rev. Plant Physiol. 14:385-410.

Israel, H. W., and F. C. Steward. 1966. The fine structure of quiescent and growing carrot cells, and its relation to growth induction. Ann. Bot. 30:63-80.

Jacob, F., and J. Monod. 1963. Genetic repression, allosteric inhibition and cellular differentiation, p. 30-64. In M. Locke (ed.) Cytodifferentiation and macromolecular synthesis. 21st symp. Society for the Study of Development and Growth. Ronald Press, New York.

Jeffs, R. A., and D. H. Northcote. 1967. The influence of indol-3/yl acetic acid and sugar on the pattern of induced differentiation in plant tissue culture. J. Cell Science 2:77-88.

Kiesselbach, J. 1948. Endosperm type as a physiological factor in corn yields. J. Amer. Soc. Agron. 40:216-236.

Knox, R. B., and L. T. Evans. 1966. Inflorescence initiation in Lolium temulentum L. VIII. Histochemical changes at the shoot apex during induction. Aust. J. Biol. Sci. 19:233-245.

Kriedemann, P. 1966. The photosynthetic activity of the wheat ear. Ann. Bot. $30: 349-364$.

Kursanov, A. L. 1963. Metabolism and the transport of organic substances in the phloem, p. 209-278. In R. D. Preston (ed.) Advances in botanical research, 1. Academic Press, London \& New York.

Lang, A. 1965a. Progressiveness and contagiousness in plant differentiation and development. Encycl. of Plant Physiol. 15:409-423. 
Lang, A. 1965b. The physiology of flower initiation. Encycl. of Plant Physiol. $15: 1380-1536$.

Leopold, A. C. 1961. Senescence in plant development. Science 134:1727-1732.

Loomis, W. E. 1935. The translocation of carbohydrates in maize. Iowa State Coll. J. Sci. 9:509-520.

Loomis, W. E. 1953. Growth correlation, p. 197-218. In W. E. Loomis (ed.) Growth and differentiation in plants. Iowa State College Press, Ames, Iowa.

Madec, P. 1963. Tuber-forming substances in the potato, p. 124-130. In J. D. Ivins and F. L. Milthorpe (ed.) The growth of the potato. Butterworths, London.

Maekawa, T. 1927. On intersexualism in Arisaema japonica. Jap. J. Bot. 3:205216.

Maggs, D. H. 1963. The reduction of growth of apple trees brought about by fruiting. J. Hort. Sci. 38:119-128.

Mangelsdorf, P. C., R. S. MacNeish, and W. C. Galinat. 1964. Domestication of of corn. Science 143:538-545.

Milthorpe, P. L. 1963. Some aspects of plant growth, p. 7-11. In J. D. Ivins and F. I. Milthorpe (ed.) The growth of the potato. Butterworths, London.

Mohan Ram, H. Y., and F. C. Steward. 1964. The induction of growth in explanted tissue of the banana fruit. Can. J. Bot. 42:1559-1579.

Molisch, H. 1938. The longevity of plants. Science Printing Co., Pennsylvania.

Moorby, J. 1968. The influence of carbohydrate and mineral nutrient supply on the growth of potato tubers. Ann. Bot. 32:57-68.

Moss, D. N. 1962. Photosynthesis and barrenness. Crop Sci. 2:366-367.

Moss, G. I., and J. Heslop-Harrison. 1968. Photoperiod and pollen sterility in maize. Ann. Bot. 32:833-846.

Mothes, K. 1964. The role of kinetin in plant regulation, p. 131-142. In J. P. Nitsch (ed.) Régulateurs Naturel de la Croissance Végétale. Coll. Internat. Centre Nat. Recherche Scientifique No. 123. Paris.

Murneek, A. E. 1926. Effects of correlation between vegetative and reproductive growth in the tomato (Lycopersicon esculentum). Plant Physiol, 1:3-56.

Nitsch, J. P. 1952. Plant hormones in the development of fruits. Quart. Rev. Biol. 27:33-57.

Nitsch, J. P. 1966. Photopériodisme et tubérisation. Bull. Soc. Franc. Physiol. Végét. $12: 233-246$.

Nitsch, J. P., and C. Nitsch. 1969. Haploid plants from pollen grains. Science $163: 85-87$.

Nösberger, J., and E. C. Humphries. 1965. The influence of removing tubers ondry matter production and net assimilation rate of potato plants. Ann. Bot. $29: 579-588$.

Nösberger, J., and G. N. Thorne. 1965. The effect of removing florets or shading the ear of barley on production and distribution of dry matter. Ann. Bot. $29: 635-644$.

Nougarède, A. 1965. La méristème caulinaire de Angiosperms: problèmes posés par la passage à la phase réproductrice. Bull. Soc. Franç. Physiol. Végét. 11:105-137.

Osborne, D. J. 1962. Effect of kinetin on protein and nucleic acid metabolism in Xanthium leaves during senescence. Plant Physiol. 37:595-602.

Osborne, D. J. 1967. Hormonal regulation of leaf senescence. Soc. Exp. Biol. Symp. 21, 305-321.

Peterson, C. E., and L. D. Ahnders. 1960. Induction of staminate flowers on gynoecious cucumbers with gibberellin As. Science 131:1673-1674.

Peterson, C. E. 1960. A gynoecious inbred line of cucumbers. Mich. Agr. Exp. Sta. Quart. Bull. 43:40-42.

Pozsar, B. I. and Z. Kiraly. 1964. Cytokinin-like effect of rust infections in the regulation of phloem transport and senescence, p. 199-210. In Z. Kiraly and G. Ubrizsy (ed.) Host-parasite relationships in plant pathology. Pubs. Res. Inst. Plant Protection, Budapest. 
Ryle, G.J.A. 1963. Studies on the physiology of flowering of timothy (Phleum pratense): III. Effects of shoot age and nitrogen level on the size of the inflorescence. Ann. Bot. 27:467-480.

Ryle, G.J.A. 1965. Effects of daylength and temperature on ear size in S24 perennial ryegrass. Ann. Appl. Biol. 55:107-114.

Ryle, G.J.A. 1966. Physiological aspects of seed yield in grasses, p. 106-117. In F. L. Milthorpe and J. D. Ivins (ed.) The growth of cereals and grasses. Butterworths, London.

Ryle, G.J.A. 1967. Effects of shading on inflorescence size and development in temperate perennial grasses. Ann. Appl. Biol. 60:297-308.

Sacher, J. A. 1967. Studies of permeability, RNA and protein turnover during aging of fruit and leaf tissues. Soc. Exp. Biol. Symp. 21:269-304.

Salisbury, F. B. 1963. The flowering process. Macmillan, New York.

Simon, E. W. 1967. Types of leaf senescence. Soc. Exp. Biol. Symp. 21:215-230.

Slater, J. W. 1963. Mechanism of tuber initiation in the potato, p. 114-120. In F. L. Milthorpe and J. D. Ivins (ed.) The growth of cereals and grasses. Butterworths, London.

Steeves, T. A. 1962. Morphogenesis in isolated fern leaves, p. 117-151. In D. Rudnick (ed.) Regeneration. 20th Symp. Society for the Study of Development and Growth. Ronald Press Co., New York.

Stern, H. 1964. Concepts and mechanisms underlying intracellular regulation, p. 19-21. In J. P. Nitsch (ed.) Régulateurs Naturel de la Croissance Végétale. Coll. Internat. Centre Nat. Recherche Scientifique No. 123. Paris.

Steward, F. C., M. O. Mapes, A. E. Kent, and R. D. Holsten. 1964. Growth and development of cultured plant cells. Science 143:20-27.

Sussex, I. 1954. Experiments on the cause of dorsiventrality in leaves. Nature 174:351-352.

Sussex, I. 1955. Morphogenesis in Solanum tuberosum: an experimental investigation of leaf dorsiventrality and orientation in the juvenile shoot. Phytomorphology $5: 286-300$.

Thimann, K. V., and F. Skoog. 1934. On the inhibition of bud development and other functions of growth substances in Vicia faba. Proc. Roy. Soc. B. 114: 317-329.

Thomas, T. H., P. F. Wareing and P. M. Robinson. 1965. Action of the sycamore dormin as a gibberellin antagonist. Nature 205:1269-1272.

Thorne, G. N. 1963. Distribution of dry matter between ear and shoot of Plumage Archer and Proctor barley grown in the field. Ann. Bot. 27:245-252.

Thorne, G. N. 1965. Photosynthesis of ears and flag leaves of wheat and barley. Ann. Bot. 29:317-329.

Thorne, G. N. 1966. Physiological aspects of grain yield in cereals, p. 88-105. In F. L. Milthorpe and J. D. Ivins (ed.) The growth of cereals and grasses. Butterworths, London.

Thorne, G. N., and A.F. Evans. 1964. Influence of tops and roots on net assimilation rate of sugar-beet and spinach/beet and grafts between them. Ann. Bot. $28 ; 499-508$.

Thorne, G. N., M. A. Ford and D. J. Watson. 1968. Growth, development, and yield of spring wheat in artificial climates. Ann. Bot. 32:425-446.

Tizio, R. 1964. Action de l'acide gibbérellique sur la tubérisation de la pomme de terre. C. R. Acad. Sci. Paris 259:1187-1190.

Tizio, R. 1966. Présence de kinines dans le périderme de tubercules de pomme de terre. C. R. Acad. Sci. Paris 262:868-869.

Walkley, J. 1940. Protein synthesis in mature and senescent leaves of barley. New Phytol. 39:362-369.

Wanner,H. 1958. Physiologie de Speicherung. Encyclopedia of Plant Physiology $6: 834-865$.

Wardlaw, C. W. 1949. Experiments on organogenesis in ferns. Growth (Suppl.) $13: 93-131$. 
Wareing, P. F., H. M. E1-Antalby, J. Good, and J. Manuel. 1967. The possible role and mode of action of abscisin (dormin) in the regulation of plant growth and development, p. 667-672. In Wachstumsregulatoren bei Pflanzen. Gustav Fischer Verlag, Jena.

Wareing, P. F., and A. K. Seth. 1967. Ageing and senescence in the whole plant. Soc. Exp. Biol. Symp. 21:543-558.

Waters, L. C., and L. S. Dure. 1966. Ribonucleic acid synthesis in germinating cotton seeds. J. Mol. Biol. 19:1-27.

Watson, D. J., G. N. Thorne, and S. A. W. French. 1963. Analysis of growth and yield of winter and spring wheats. Ann. Bot. 27:1-22.

Weber, H. 1958a. Morphologisch-anatomische Grundlagen de Speicherung. Encycl. Plant Physiol. 6:817-828.

Weber, H. 1958b. Bedeutung der Speicherung. Encycl. Plant Physiol. 6:829-833.

Welbank, P. J., S. A. W. French, and K. J. Witts. 1966. Dependence of yields of wheat varieties on their leaf area durations. Ann. Bot. 30:291-299.

Went, F.W. 1957. The experimental control of plant growth. Chronica Botanica Co., Waltham, Mass.

Went, F.W., and R. Engelsberg. 1946. Plant growth under controlled conditions. VII. Sucrose content of the tomato plant. Arch. Biochem. 9:187-200.

Wetmore, R. H., and J.P.Rier. 1963. Experimental induction of vascular tissue in callus of angiosperms. Amer. J. Bot. 50:418-430.

Wickson, M., and K. V. Thimann. 1958. On the antagonism of auxin and kinetin in apical dominance. Physiol. Plant. 11:62-74.

Wollgiehn, R. 1965. Kinetin und Nucleinsaurestoffwechsel. Flora 156A:291-302.

Wollgiehn, R. 1967. Nucleic acid and protein metabolism in excised leaves. Symp. Soc. Exp. Biol. 21:231-246.

Zimmerman, P. W., and A. E. Hitchcock. 1936. The localisation of the mechanism which regulates tuberisation in plants. Amer. J. Bot. 23:690-696.

\title{
13...DISCUSSION
}

\author{
NORMAN E. GOOD
}

Michigan State University

East Lansing, Michigan

Since my professional contact with plants is confined to the contemplation of homogenates of spinach leaves (Spinacia oleracea), I am not able to add much to Dr. Heslop-Harrison's very thorough discussion of the role of differentiation in crop production; nothing obliterates the results of differentiation more quickly or more thoroughly than a Waring blender. Therefore, I propose to confine my remarks to a rather general philosophical consideration of the regulation of photosynthesis by factors which reside in the plant itself. The topics I want to touch on briefly are the following:

1) The implications of the "source-sink" conception of the regulation of photosynthesis rates. 
2) Differentiation as a factor in determining source-sink relationships.

3) Possible mechanisms of feed-back control of photosynthesis.

There are excellent a priori reasons for expecting photosynthesis to be regulated, in part at least, by the demand of the organism for the products of photosynthesis. Only those machines which use energy for a single purpose can be satisfactorily regulated at the energy input level. Thus an automobile functions adequately with a single control of energy input (the accelerator) because the energy is being used almost exclusively to push the car down the road. But one need only turn to the electrical system of the same car to see how unsatisfactory is control of a multipurpose system at the input. If the battery did not have a very large excess capacity the lights would go out when the windshield wipers were turned on! In the respiration of higher organisms one encounters the same principle. Respiration is normally controlled by the utilization of energy (i.e., the utilization of ATP controls the level of ADP which controls the respiratory rate). Control of respiration at the substrate level is usually a pathological condition known as starvation. It would be surprising indeed if the same principle did not apply to photosynthesis. Indeed it would be intolerable if the plant were unable to shut off photosynthesis when its growth processes can cope with no more photosynthesis products. The plant would no longer have control of its own growth and development.

Fortunately we do not have to rely on this sort of deductive reasoning, which is always somewhat dangerous when we lack even a qualitative knowledge of the processes involved. Abundant direct evidence of the control of photosynthesis by the plant's requirements has been presented in the literature. Many instances have been reported in discussions at this symposium. I would like to add yet another case. One of our hosts, Dr. Daly and his student, Dr. Livne, have reported (Livne and Daly, 1966) on a controlled sink. When a primary leaf of a bean plant (Phaseolus sp.) is infected with rust its photosynthesis falls and and its respiration rises. With progressively more severe infections the leaf is converted from an exporter to an importer, that is from a source into a sink. At the same time the photosynthesis of the uninfected trifoliate leaf above increases, ultimately almost doubling. Not only does this experiment offer a unique opportunity to produce sources and sinks of varying intensity. It also provides considerable quantitative information about one of the roles of disease in determining crop productivity-an aspect of productivity which may not have been considered adequately in our meetings this week.

In spite of the abundant evidence that photosynthesis can be controlled by internal factors (which have been lumped together as "sink size") this concept has not been accepted unanimously. We have heard of experiments which seemingly conflicted with the concept-decreases in yield in spite of an apparent increase in the size of the sink. This conflict of interpretation brings me to my next topic, the role of differentiation in determining source-sink relationships. It seems to me that our thinking on this matter has been distortedly an overly simplistic picture of source-sink relationships. Too often we have been considering two bathtubs connected by a pipe. In reality the "sink" is infinitely 
complex, consisting as it does of the entire catabolism of the plant. It is an ever-changing network of pathways with ever-changing flows of photosynthetic products directed toward a multitude of sinks, each pathway controlled at different sites by different rate-determining steps. Overall control of this multitude of rate-determining steps is synonymous with differentiation. Consequently source-sink relationships are modified by anything which modifies differentiation-genetics, photoperiods, the form-modifying effects of light and temperature, endogenous and exogenous hormones, etc. Operations such as the removal of plant parts on the stimulation of fruit set may or may not influence the network of pathways of catabolism, and hence the sink size, depending on whether or not such operations affect the control of some ratedetermining step in the network. We must not be surprised to find that some induced changes, which on first thought should increase or decrease the sink for photosynthates, do no such thing. No experiment has any relevance to "sinks" unless it is clear that a regulated, ratedetermining step has been modified by the operation.

Assuming, as we must, I think, that the control of photosynthesis by internal factors is an established fact, let us now ask some questions about possible mechanisms by which this control might be exercised. What are some of the ways in which photosynthesis could be inhibited when there is a sufficiency of photosynthesis products?

Is there a pileup of intermediates which stop the process by mass action at some reversible step? Or do we have here an analogy to respiration, the supply of some catalytic intermediate decreasing when an acceptor cannot be found? What is the site of inhibition in biochemical terms - that is to say, what accumulates and what decreases, if anything, when plants with full stomachs are enjoying their midday siesta?

Do the stomates close?

Does some sort of message (hormone?) come to the photosynthetic machinery, telling it to slow down? (Herein lies a trap: we must not confuse effects of hormones on differentiation and hence on the sinks for photosynthate with possible direct effects of hormones as coordinators of the source-sink relationship. A hormone could increase photosynthesis by influencing directly the photosynthetic controls but no such interpretation of hormone action is justified or even reasonable until the effects on the demand for photosynthate have been evaluated.)

Does photorespiration increase during siesta? In other words, is net photosynthesis controlled by the magnitude of a back-reaction?

I am sorry to end with many questions and no answers. If the answers to any of them are known, you will have to blame the organizers of the symposium for asking a contemplator of homogenates to comment on differentiation. If, as I suspect, none of the answers are known, we can reasonably hope that some will be supplied at the next symposium on the physiology of crop production.

\section{LITERATURE CITED}

Livne, A., and J. M. Daly. 1966. Translocation in healthy and rust-affected beans. Phytopathology 56:170-175. 
WALTER E. LOOMIS

lowa State University

Ames, lowa

Dr. Heslop-Harrison, as expected, has covered the topic of Development, Differentiation, and Yield very thoroughly. I will, therefore, limit my remarks to brief discussions of work which supports and illustrates some of the points he has made.

\section{Winter Hardiness}

Winter hardiness may be taken as a model of cytoplasmic differentiation, directly related to the sugar levels within the tissue, but dependent upon specific genes which control metabolism. In a very cold winter in Iowa, the winter hardy 'Grimm' alfalfa (Medicago sativa L.) survived without injury if the sucrose content of the roots was $4 \%$, fresh-weight, in December, but was injured or killed when the sugar content was lower. 'Kansas Common' did not survive with less than $8 \%$ of sucrose and 'Arizona Common' was nonhardy, even with $12 \%$ sucrose. Sucrose, we assume, is the differentiation material, but it was effective only when the necessary genes were present. Similar responses are shown in many reactions-in drouth resistance and in the development of some fruit colors for example.

\section{Translocation}

Translocation is very specifically related to differentiation and embryo development infruits. When older varieties of maize (Zea mays L.) were grown in single-stalk hills and allowed to develop two large suckers, defoliation of the main stalk 2 days before silking stopped all development of the floral axis and pistillate flowers. The same defoliation 7 days after silking resulted in the production of full-sized ears on the defoliated stalks with translocation from leaves on earless branch stalks $2 \mathrm{~m}$ away from the ear. Some grain was produced on stalks defoliated 2 days after silking, with the response rising rapidly with the initiation of embryo development in the pollinated grains.

Apples (Malus sylvestris Mill.) show a similar response. Defoliation of a flowering spur shortly before bloom prevents fruit development. Ten days after flowering normal fruits were produced when all leaves were removed within $2 \mathrm{~m}$ of the fruiting spurs. It is assumed that hormones produced by the developing embryos of seeds and fruits channel food toward these organs.

Rapid translocation of foods occurs into embryonic and young leaves 
of sugar beet, but is blocked as the leaves approach maturity. If the plant is covered to exclude light, embryonic leaves develop normally, but mature leaves starve quickly in spite of large reserves in the root. Some alteration in the phloem is considered to be responsible.

\section{Antihormones as Florigens}

Several years ago we discovered at Iowa State University that soybean plants (Glycine max L.) could be forced into flower on days 2 to 3 hours too long for normal flowering by spraying them with nicotine sulfate. This chemical appears to be specific for soybeans. TIBA $(2,3,5-$ triiodobenzoic acid) sprays and the removal of young, growing leaves from the upper plant have, however, been even more effective than nicotine sulfate, and both treatments are expected to reduce the auxin content of the plants and thus permit flower-bud differentiation. NAA (naphthalene acetic acid) sprays applied alone on short-day plants have prevented flowering, but when applied hours after TIBA on long-day plants, have increased total bloom, indicating that flower-bud differentiation proceeds rapidly, and that auxin functions in the development of flowers, as opposed to the initial differentiation of buds.

\section{Antihormones and Flowering of Apples}

TIBA sprays applied just after the time of petal drop can greatly increase flowering on young trees in the next year. Spraying with the growth retardant, Alar (succinamic acid-2, 2-dimethyl hydrazide), can have the same effect. NAA sprays can almost eliminate flowering the next year. Interstem grafts of short pieces of Paradise, "dwarfing" stocks increase subsequent flowering and show antihormone responses.

Antiauxin sprays, interstem gra fts with 'Paradise' stocks, or ringing the stem above the roots all greatly increase root sprouting from essentially zero to dozens of sprouts per tree per year. Applying NAA in a lanolin paste on a ringed stem or to the bark in other treatments which increase sprouting, prevents this response. We interpret these responses as indicating that growth hormones can prevent flower-bud differentiation and that treatments which lower the concentration of these substances can initiate flowering and fruiting responses. 